\title{
Effects of insulin and hydrocortisone on lung tissue phosphatidyl choline and disaturated phosphatidyl choline in fetal rabbits in vivo
}

\author{
D. M.Patel and P.G. Rhodes \\ University of Mississippi Medical Center, Jackson, Mississippi, USA
}

\begin{abstract}
Summary. To determine the effects of insulin and hydrocortisone on lung tissue surfactant, the fetuses of New Zealand White rabbits were injected with insulin, saline $(0.154 \mathrm{~mol} / \mathrm{l})$, insulin + hydrocortisone, insulin + saline or saline + hydrocortisone, or were sham-operated on day 27 of gestation. Twenty-four hours later (on day 28 of gestation) delivery was accomplished by Caesarian hysterectomy. The lung tissues were analysed for phosphatidyl choline and disaturated phosphatidyl choline. Both were higher in fetuses injected with insulin than in sham-operated control animals. The phosphati-
\end{abstract}

dyl choline and disaturated phosphatidyl choline were also higher in the fetuses injected with insulin + hydrocortisone than in fetuses injected with insulin or hydrocortisone alone. These results suggest that insulin increases the phosphatidyl choline and disaturated phosphatidyl choline content in lung tissue in fetal rabbits in vivo, and that in the presence of hydrocortisone, insulin appears to have an additive effect.

Key words: Phosphatidyl choline, disaturated phosphatidyl choline, surfactant, insulin, hydrocortisone, rabbit fetus.
Hyaline membrane disease (HMD) in pre-term infants is primarily due to inadequate surfactant, mainly phosphatidyl choline [1, 2]. As well as being large for gestational age, infants of diabetic women have multiple problems at birth. The increased incidence of HMD compared with that in infants of similar gestational age born to normal women is a major concern because of its life-threatening nature [3-5]. The fetus of a poorly controlled diabetic woman has hyperglycaemia causing hyperinsulinaemia in utero [6,7]. It is less certain that hyperadrenocorticism exists in these infants [8-10]. Although the underlying pathophysiology is unclear, hyperinsulinaemia has been implicated as a major factor in delayed lung maturation.

Animals with chemically-induced diabetes have been used to study the pathophysiology of the hyaline membrane disease in these infants. The effects of cortisol on fetal lung cellular growth and surfactant maturity are well established, in both animals and human infants [11-13]. Smith et al.in a lung tissue-culture study [14], showed that insulin alone has a positive effect on choline incorporation into lecithin. However, when the lung tissue was incubated with cortisol, all concentrations of insulin were significantly associated with reduced lecithin synthesis. Gewolb et al. showed that pulmonary glycogen degradation is delayed in fetuses of rats with streptozotocin-induced diabetes, and delay in lung maturation may be related to decreased activity of glycogenolytic enzyme phosphorylase A, resulting in decreased availability of glucose for surfactant synthesis [15]. In rabbits with alloxan-induced diabetes, fetal hyperglycaemia is seen, whereas fetal hyperinsulinaemia is absent [16]. Also, in rats with streptozotocin-induced diabetes the fetal pancreatic islet cells are not hyperplastic or hypertrophied, as they are in the fetus of a diabetic woman $[17,18]$. To our knowledge, the status of adrenocorticosteroid in these animals is unknown.

This study was designed to evaluate the combined effects of insulin and hydrocortisone on lung-tissue phosphatidyl choline and disaturated phosphatidyl choline synthesis in rabbits in vivo, in the absence of changes in the metabolic status of the doe or fetuses.

\section{Materials and methods}

\section{Animals}

New Zealand White rabbit does (age at breeding 6 months or above and weight between 3 and $4 \mathrm{~kg}$ ) were bred, the time of mating being known to within $8 \mathrm{~h}$. The day of mating was considered as day zero of gestation. On day 27 of gestation, pregnancy was confirmed by palpation after intravenous administration of ketamine $(5-10 \mathrm{mg} / \mathrm{kg})$ to achieve relaxation.

Group 1: Fetuses in the right uterine horn received a mixture of regular and protamine zinc insulins $(0.5$ units each $)+1 \mathrm{mg}$ hydrocortisone (total volume $0.2 \mathrm{ml}$ ) and fetuses in left uterine horn were injected 
Table 1. Fetal weights and serum glucose, cortisol and insulin levels

\begin{tabular}{|c|c|c|c|c|c|}
\hline Group & Injection & $\begin{array}{l}\text { Fetal weight } \\
\text { (g) }\end{array}$ & $\begin{array}{l}\text { Serum glucose } \\
(\mathrm{mmol} / 1)\end{array}$ & $\begin{array}{l}\text { Serum cortisol } \\
(\mathrm{nmol} / 1)\end{array}$ & $\begin{array}{l}\text { Serum insulin } \\
(\mathrm{mU} / \mathrm{l})\end{array}$ \\
\hline \multirow[t]{2}{*}{1} & $\begin{array}{l}\text { Insulin }+ \\
\text { hydrocortisone }\end{array}$ & $\begin{array}{l}24.7 \pm 2.1 \\
(7)\end{array}$ & $\begin{array}{l}4.24 \pm 0.42 \\
\text { (7) }\end{array}$ & $\begin{array}{l}83.1 \pm 18.2^{\mathrm{a}} \\
(7)\end{array}$ & $\begin{array}{l}65.6 \pm 15.5 \\
(6)\end{array}$ \\
\hline & Insulin + saline & $\begin{array}{l}25.8 \pm 1.8 \\
(7)\end{array}$ & $\begin{array}{l}4.37 \pm 0.20 \\
(7)\end{array}$ & $\begin{array}{l}30.9 \pm 2.7 \\
(7)\end{array}$ & $\begin{array}{l}73.0 \pm 10.5 \\
(6)\end{array}$ \\
\hline & $\begin{array}{l}\text { Saline }+ \\
\text { hydrocortisone }\end{array}$ & $\begin{array}{l}28.5 \pm 3.2 \\
\text { (9) }\end{array}$ & $\begin{array}{l}4.84 \pm 0.29 \\
(9)\end{array}$ & $\begin{array}{l}38.1 \pm 6.6 \\
(9)\end{array}$ & $\begin{array}{l}31.3 \pm 3.9 \\
(9)\end{array}$ \\
\hline \multirow[t]{2}{*}{3} & Saline alone & $\begin{array}{l}27.6 \pm 2.2 \\
(6)\end{array}$ & $\begin{array}{l}5.50 \pm 0.46 \\
(6)\end{array}$ & $\begin{array}{l}42.5 \pm 17.1 \\
(5)\end{array}$ & $\begin{array}{l}38.3 \pm 3.4 \\
(6)\end{array}$ \\
\hline & Sham-operated & $\begin{array}{l}29.2 \pm 5.5 \\
(6)\end{array}$ & $\begin{array}{l}4.39 \pm 0.80 \\
(6)\end{array}$ & $\begin{array}{l}36.4 \pm 6.2 \\
(5)\end{array}$ & $\begin{array}{l}53.5 \pm 13.5 \\
(6)\end{array}$ \\
\hline & Sham-operated & $\begin{array}{l}28.5 \pm 1.4 \\
(7)\end{array}$ & $\begin{array}{l}6.00 \pm 0.80 \\
(7)\end{array}$ & $\begin{array}{l}30.6 \pm 3.0 \\
(7)\end{array}$ & $\begin{array}{l}30.3 \pm 1.8 \\
(7)\end{array}$ \\
\hline
\end{tabular}

Values expressed as mean \pm SEM with number of does in parentheses. ${ }^{a} p<0.05 ;{ }^{b} p<0.025 ;{ }^{c} p<0.0005$ : significant differences between the animals in each group

with the same mixture of insulin + saline $(0.154 \mathrm{~mol} / 1$; total volume $0.2 \mathrm{ml}$ ) to serve as controls.

Group 2: Fetuses in the right uterine horn were injected with a mixture of regular and protamine zinc insulins $(0.5$ units each $)+1 \mathrm{mg}$ hydrocortisone (total volume $0.2 \mathrm{ml}$ ) and fetuses in left uterine horn were injected with saline $(0.154 \mathrm{~mol} / \mathrm{l})+1 \mathrm{mg}$ hydrocortisone (total volume $0.2 \mathrm{ml}$ ) to serve as controls.

Group 3: Fetuses in the the right uterine horn were injected with saline $(0.154 \mathrm{~mol} / 1$; total volume $0.1 \mathrm{ml})$ and the fetuses in left uterine horn were considered as sham-operated controls.

Group 4: Fetuses in the right uterine horn were injected with a mixture of regular and protamine zinc insulins $(0.5$ units each; total volume $0.1 \mathrm{ml}$ ) and the fetuses in left uterine horn were considered sham-operated controls.

\section{Experimental design}

On day 27 of gestation, after confirmation of pregnancy, the uterus was exteriorized through a midline incision under pentobarbital anaesthesia $(20 \mathrm{mg} / \mathrm{kg})$. One fetus at a time was injected through the uterine wall in the hind leg or rump. During injection each fetus was stabilized against the uterine wall. Two to four fetuses on each side were injected. The total number of fetuses varied from two to eight on each side. When there were more than four fetuses in one uterine horn, four fetuses were injected sequentially starting from the top of the uterine horn and the remaining fetuses were not used in the experiment. Following injection, the uterus was returned to the abdominal cavity and the incision closed. Intravenous dextrose (5\%) and saline $(77 \mathrm{mmol} / \mathrm{l})$ were infused until the doe recovered from anaesthesia (average recovery time $2 \mathrm{~h}$ ). Other investigators have used similar injection techniques to study the effects of insulin and cortisol $[12,19]$.

On day 28 of gestation ( $24 \mathrm{~h}$ after injection), the fetuses were deliv. ered by Caesarian hysterectomy under pentobarbital anaesthesia $(25 \mathrm{mg} / \mathrm{kg})$. The necks of the fetuses were tied at birth to prevent breathing.

Fetal blood from two randomly-selected injected fetuses from each side of uterus was collected by cardiac puncture and pooled for determination of serum glucose, insulin and cortisol concentrations. The lungs from the same two fetuses were removed and pooled for determination of phosphatidyl choline (PC) and disaturated PC (DSPC).

\section{Laboratory methods}

Serum glucose was determined by a glucose oxidase method using a glucose analyser (Beckman, Brea, California, USA). Serum insulin and cortisol were determined by radioimmunoassay, using Micromedic radioimmunoassay kits (Diagnostic Product Corporation, Los Angeles, California, USA).

After slicing and mixing, the lung tissue was divided into small portions and weighed. Part was used for determination of $\mathrm{PC}$, another part for determination of DSPC, and the remainder was frozen and stored.

After homogenization of the lung tissue, chloroform-methanol and ether-hexane were used to extract phospholipids as described by Russell et al. [20]. PC was isolated by thin layer chromatography, using chloroform: methanol: glacial acetic acid: water (138:87:18:9 by volume) as a developing solvent [20]. The PC on thin layer chromatograph plates was identified by exposing the plate to iodine vapour.

After extraction of phospholipid from the lung tissue by the same method, DSPC was separated by the method of Mason et al. [21] in which phospholipid extract was oxidized using osmium tetroxide and passed through an activated aluminium oxide column (solvent 1: chloroform:methanol $20: 1$ by volume; solvent 2 :chloroform: methanol:ammonium hydroxide $7 \mathrm{~mol} / 1$ 70:30:2 by volume). The recovery of DSPC in our laboratory with this procedure is $85-90 \%$.

Phosphorus content was determined by the method of Rosenthal et al. [22].

\section{Statistical analysis}

All four groups were analysed separately. Statistical analysis comparing fetal weights, serum glucose levels, serum insulin concentrations, serum cortisol levels, lung-tissue PC and lung-tissue DSPC were carried out using Student's two-tailed paired t-test. 

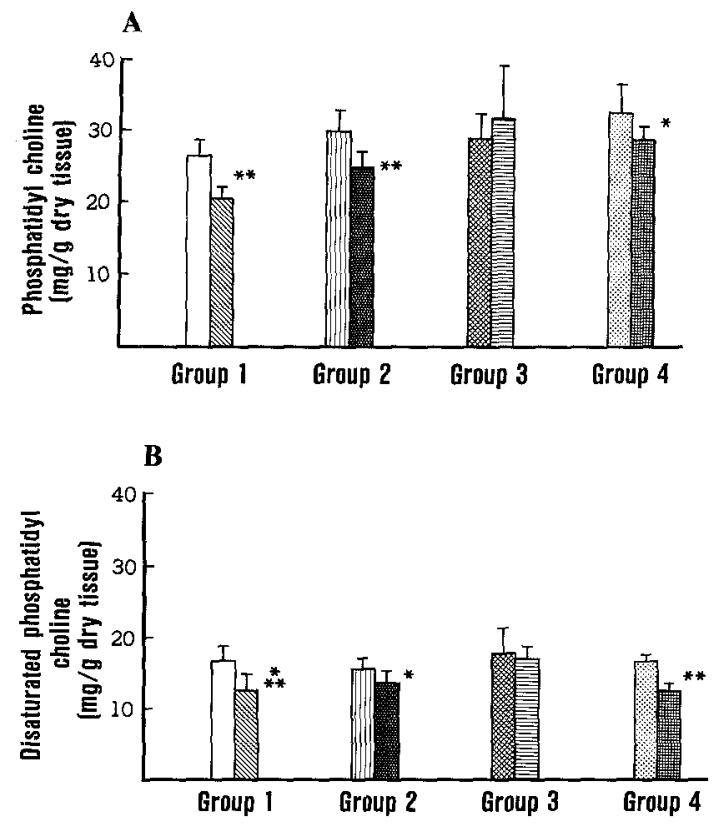

Fig. 1. A Lung tissue phosphatidyl choline and B lung tissue disaturated phosphatidyl choline (mean $\pm \mathrm{SEM}$ ). ${ }^{*} p<0.05 ; * * p<0.01$; ${ }^{* * *} p<0.005$ (Student's two-tailed paired t-test). Group 1 (seven does) $\square=$ insulin +hydrocortisone, $\mathbb{N}=$ insulin + saline; group 2 (nine does) $\mathbb{⿴ 囗 十}=$ insulin + hydrocortisone, $\quad$ =saline + hydrocortisone; group 3 (six does) 图=saline alone, 目=sham-operated; group 4 (seven does) 0 : insulin alone, 娄 $=$ sham-operated

\section{Results}

Data from seven rabbit does in group 1, nine in group 2, six in group 3 and seven in group 4 are available.

The fetal weights and serum glucose concentrations were similar in all four groups (Table 1). The mean serum insulin concentrations were similar in groups 1 and 3 , but as expected were significantly higher in the fetuses injected with insulin in groups 2 and $4(p<0.05$ and $<0.0005$ respectively; Table 1$)$. As expected, in group 1 the mean serum cortisol level was higher in fetuses injected with insulin +hydrocortisone than in those injected with insulin + saline $(p<0.05$; Table 1$)$. The serum cortisol concentration was also higher in the insulin-injected than in the sham-operated fetuses $(p<$ 0.025; Table 1).

The mean $\pm S E M$ levels of the lung-tissue $\mathrm{PC}$ in all four groups are shown in Figure 1A. In group 1, the mean fetal lung-tissue PC was higher after insulin + hydrocortisone than after insulin + saline injection $(26.1 \pm 2.2$ versus $20.2 \pm 1.8 \mathrm{mg} / \mathrm{g}$ dry tissue; $p<0.01$ ). Similarly, in group 2 the mean lung-tissue PC in fetuses injected with insulin + hydrocortisone was higher than in those injected with saline +hydrocortisone $(29.9 \pm$ 2.8 versus $24.7 \pm 2.3 \mathrm{mg} / \mathrm{g}$ dry tissue; $p<0.01$ ). In group 3, there was no difference in lung-tissue PC between saline-injected and sham-operated fetuses ( $28.8 \pm 3.3$ versus $31.4 \pm 7.4 \mathrm{mg} / \mathrm{g}$ dry tissue). In group 4 , lung-tissue $\mathrm{PC}$ was higher in insulin-injected than in sham-operated fetuses $(34.4 \pm 4.4$ versus $30.0 \pm$ $3.2 \mathrm{mg} / \mathrm{g}$ dry tissue; $p<0.05$ ).

The mean \pm SEM levels of the lung-tissue DSPC are shown in Figure 1 B. In group 1, DSPC was higher after insulin + hydrocortisone than after insulin + saline-injection $(16.8 \pm 2.6$ versus $12.8 \pm 2.6 \mathrm{mg} / \mathrm{g}$ dry tissue; $p<0.0005$ ). In group 2, it was higher in fetuses injected with insulin + hydrocortisone than in those injected with saline + hydrocortisone $(15.4 \pm 1.5$ versus $13.6 \pm$ $1.7 \mathrm{mg} / \mathrm{g}$ dry tissue; $p<0.05$ ). In group 3 , there was no difference in lung-tissue DSPC between saline-injected and sham-operated fetuses $(18.0 \pm 3.3$ versus $16.9 \pm$ $1.4 \mathrm{mg} / \mathrm{g}$ dry tissue). In group 4 , it was higher in insulininjected than in sham-operated offspring ( $16.8 \pm 0.7$ versus $12.5 \pm 0.7 \mathrm{mg} / \mathrm{g}$ dry tissue; $p<0.01$ ).

\section{Discussion}

These results indicate that in fetal rabbits, insulin by itself increases the PC and DSPC content of lung tissue in vivo. These findings in part correlate with studies in vitro reported by Smith et al. [14] and Gross et al. [23]. Warburton et al. showed that chronic hyperinsulinaemia reduce flux of surface active material in tracheal fluid in lambs in vivo [24]. Rooney et al. showed that hyperinsulinaemia did not inhibit surfactant production in the fetal primate in vivo, at least up to 148 days of gestation [25]. In both studies, the hyperinsulinaemic fetuses had significantly lower serum glucose concentrations, which itself may have influenced the pulmonary surfactant surge or production. The fact that serum glucose concentrations were not different in our study may be related to the shorter duration of hyperinsulinaemia allowing fetuses to mobilize stored glycogen.

The combined effects of insulin and cortisol on lung-tissue surfactant in vivo are unknown. In this study the finding that PC and DSPC content was greater in the fetuses injected with insulin + hydrocortisone than in litter-matched fetuses injected with insulin alone (group 1) or with hydrocortisone alone (group 2) indicates an additive effect of the drug combination. This additive effect contrasts with the in vitro study of Smith et al. [14]. However, in monkey studies, Beck et al. showed that glucocorticoids induced hyperinsulinaemia, which resulted in decreased surfactant synthesis, but pulmonary compliance was unaffected [26]. The serum cortisol levels in insulin-injected fetuses in group 4 were significantly higher, indicating that insulin may play some role in altering cortisol, thus indirectly affecting PC and DSPC in lung tissue. Since serum cortisol concentrations were not different in group 3 , the stress effect of the procedure itself was not responsible. We have not tested pulmonary compliance changes in this study and are thus unable to comment on the functional effect of insulin, whether given alone or combined with hydrocortisone. Likewise, the effects on fetal rabbits of 
hyperinsulinaemia of longer duration, with or without hydrocortisone, have yet to be tested.

Hyaline membrane disease in infants born to diabetic women is a complex problem and may be multifactorial. It may be that the increased incidence is related to a lack of surfactant surge to the alveolar surface [24] rather than deficiency in Type II alveolar cells. It has been suggested that lack of surfactant components other than PC and DSPC [27, 28], or alternatively factors other than fetal hyperinsulinaemia and hypercortisolaemia, may be responsible [16]. It is possible that abnormal carbohydrate metabolism plays a major role in delaying pulmonary maturity, rather than there being a direct hormonal effect on pulmonary surfactant [15].

Effects in vivo of insulin alone or insulin + hydrocortisone on pulmonary compliance and on the production of other surfactant components, such as phosphatidyl glycerol and phosphatidyl inositol, need to be evaluated for a better understanding of this complex problem.

Acknowledgements. We thank Dr. E. Meydrech for his statistical advice, Mrs. K.Summerlin and Mrs. M. Crawford for their technical help and Mrs. S. Maughon for her secretarial help. This work was supported by a grant from the Mississippi Lung Association.

\section{References}

1. Avery ME, Mead J (1959) Surface properties in relation to atelectasis and hyaline membrane disease. Am J Dis Child 97: 517-523

2. Gluck L, Kulovich MV, Borer RC, Brenmer PH, Anderson GG, Spellacy WN (1971) Diagnosis of the respiratory distress syndrome by amniocentesis. Am J Obstet Gynecol 109: 440-445

3. Allen RD, Palumbo JJ (1981) Respiratory distress and neonatal mortality in infants of diabetic and prediabetic mothers. Acta Diabet Lat 18: 101-106

4. Gluck L, Kulovich MV (1973) Lecithin/Sphingomyelin ratios in amniotic fluid in normal and abnormal pregnancy. Am J Obstet Gynecol 115: 539-546

5. Robert MF, Neff R, Hubbell J, Tawusch HW, Avery ME (1976) Association between maternal diabetes and the respiratory distress syndrome in the newborn. N Engl J Med 294: 357-360

6. Obenshain SS, Adam PAJ, King KC, Teramo KK, Raivio KO, Raiha V, Schwartz R (1970) Human fetal insulin response to sustained maternal hyperglycemia. N Engl J Med 283: 556-570

7. Shima K, Price S, Foa PP (1976) Serum insulin concentration and birth weight in human infants. Proc Soc Exp Biol Med 121: 55-59

8. Aarskog D (1963) Cortisol production rate in newborn infants of diabetic mothers. J Pediatr 62: 807-814

9. Cathro DM, Forsyth CC (1965) Excretion of corticoisteroids by infants of diabetic and pre-diabetic mothers. Arch Dis Child 40: $583-592$

10. Chattoraj SC, Carroll CJ, Turner AK, Gillespie L, Pinkus JL, Charles D (1974) Carbohydrate intolerance: its influence on maternal and fetal levels of cortisol and cortisone. Obstet Gynecol 44: 646-656
11. Liggins GC, Howie RN (1972) A controlled trial of antepartum glucocorticoid treatment for prevention of the respiratory distress syndrome in premature infants. Pediatrics 50: 515-525

12. Motoyama ED, Orzalesi MM, Kikkawa Y, Kaibara M, Wu B, Zigas CJ, Cook CD (1971) Effect of cortisol on the maturation of fetal rabbit lungs. Pediatrics 48: 547-555

13. Smith BT, Torday JS, Giroud CJP (1973) The growth promoting effect of cortisol on human fetal lungs cells. Steroids $22: 515-524$

14. Smith BT, Giroud CJP, Robert M, Avery ME (1975) Insulin antagonism of cortisol action of lecithin synthesis by cultured cells. J Pediatrics 87: 953-955

15. Gewolb IH, Barrett C, Wilson CM, Warshaw JB (1982) Delay in pulmonary glycogen degradation in fetuses of streptozotocin diabetic rats. Pediatr Res 16: 869-673

16. Bose CL, Manne DN, D'Ercole AJ, Lawson EE (1980) Delayed fetal pulmonary maturation in a rabbit model of diabetic pregnancy. J Clin Invest 66: 220-226

17. Eriksson U, Sweene I (1982) Diabetes in pregnancy: growth of the fetal pancreatic B cells in the rat. Biol Neonate 42: 239-248

18. Sweene I, Eriksson U (1982) Diabetes in pregnancy: islet cell proliferation in the fetal rat pancreas. Diabetologia 23: 525-528

19. Angervall L, Karlsson K, Martisson A (1981) Effects on rat fetuses of intrauterine injections of insulin. Diabetologia 20: 558-562

20. Russell PT, Miller WJ, McLain CR (1974) Palmitic acid content of amniotic fluid lecithin as an index of fetal lung maturity. Clin Chem 20: 1431-1434

21. Mason RJ, Nellenbogen J, Clements JA (1976) Isolation of disaturated phosphotidylcholine with osmium tetroxide. J Lipid Res 17: 281-284

22. Rosenthal AF, Sching-Hsien H (1969) Phosphorus determination in phosphoglycerides from thin layer chromatograms. J Lipid Res 10:213-215

23. Gross I, Smith AJW, Wilson CM, Maniscalco WM, Ingleson LD, Brehier A, Rooney SA (1975) The influence of hormones on the biochemical development of fetal rat lung in organ culture. Pediatr Res 14: 834-838

24. Warburton D, Lew CD, Platzker ACG (1981) Primary hyperinsulinemia reduces surface active material flux in tracheal fluid of fetal lambs. Pediatr Res 15: 1422-1424

25. Rooney SA, Chu AJ, Gross I (1983) Lung surfactant in the hyperinsulinemic fetal monkey. Lung 161:313-317

26. Beck JC, Johnson JWC, Mitzner W, Lee PA, London WT, Sly DL (1981) Glucocorticoids, hyperinsulinemia, and fetal lung maturation. Am J Obstet Gynecol 139: 465-470

27. Demottaz V, Epstein MF, Frantz III ID (1980) Phospholipid synthesis in lung slices from fetuses of alloxan diabetic rabbits. Pediatr Res 14: 47-49

28. Tsai MY, Josephson MW, Donhowe J (1983) Delayed pulmonary phosphatidylglycerol synthesis and reversal by prenatal dexamethasone in fetal rats of streptozotocin-diabetic mothers. Exp Lung Res 4: 315-323

Received: 21 November 1983

and in final form: 2 August 1984

Dr. Daksha M. Patel

Division of Newborn Medicine

University of Mississippi Medical Center

2500 North State Street

Jackson, MS 39216

USA 